\title{
Leucine-Based Polymer Architecture-Induced Antimicrobial Properties and Bacterial Cell Morphology Switching
}

\author{
Ishita Mukherjee,,$^{\dagger}$ Anwesha Ghosh, ${ }^{\ddagger}$ Punyasloke Bhadury, ${ }^{*,+, \S}$ and Priyadarsi De ${ }^{*, \dagger, \S(0)}$
}

${ }^{\dagger}$ Polymer Research Centre, Department of Chemical Sciences, ${ }^{\ddagger}$ Integrative Taxonomy and Microbial Ecology Research Group, Department of Biological Sciences, and ${ }^{\S}$ Centre for Advanced Functional Materials, Indian Institute of Science Education and Research Kolkata, Mohanpur, 741246 Nadia, West Bengal, India

\section{Supporting Information}

ABSTRACT: To evaluate the comparative antibacterial activity of leucine-based cationic polymers having linear, hyperbranched, and star architectures containing both hydrophilic and hydrophobic segments against Gram-negative bacterium, Escherichia coli (E. coli), herein we performed zone of inhibition study, minimum inhibitory concentration (MIC) calculation, and bacterial growth experiment. The highest antibacterial activity in terms of the MIC value was found in hyperbranched and star architectures because of the greater extent of cationic and hydrophobic functionality, enhancing cell wall penetration ability compared to that of the linear polymer. The absence of the bacterial regrowth stage in the growth curve exhibited the highest bactericidal capacity of star polymers, when untreated cells (control) already reached to the stationary phase, whereas the bacterial regrowth stage with a delayed lag phase was critically observed for linear and hyperbranched architectures displaying lower bactericidal efficacy. Coagulation of E. coli cells, switching of cell morphology from rod to sphere, and lengthening due to stacking in an antimicrobial polymer-treated environment at the bacterial regrowth stage in liquid media were visualized critically by field emission scanning electron microscopy and confocal fluorescence microscopy instruments in the presence of $4^{\prime}, 6$-diamidino-2-phenylindole stain.

\section{INTRODUCTION}

Recently, the emergence of drug-resistant bacteria has challenged modern science and medicine, as bacterial infections are increasingly posing threat to public health. ${ }^{1}$ The World Health Organization has recently recognized that certain bacterial pathogens have attained resistance to most of the commercially available and clinically used antibiotics. ${ }^{2}$ According to the reports of the Center for Disease Control, antibiotic confrontation after treatment with those antibiotics has been extended to 2 millions of people in the United States and lack of proper treatment caused death of 23000 individuals annually. ${ }^{3}$ Hence, there is an urgent requirement for the development of new antibacterial agents to fight against antibiotic-resistant bacteria, leading to the generation of mechanistically diverse nonantibiotics. ${ }^{4}$

These nonantibiotic treatments of chronic wound infections have led to the application of honey ${ }^{5,6}$ and silver. ${ }^{7,8}$ However, these approaches cannot be an universal remedy as silver may negotiate wound healing and honey can be difficult to handle. These problems have highlighted the clinical need to develop new approaches. ${ }^{9}$ One promising alternative approach is to generate naturally occurring host-defense antimicrobial peptides (AMPs). ${ }^{10,11}$ These peptides fold into secondary conformations such as $\alpha$-helix or $\beta$-sheet after binding to bacterial cell membranes, followed by the penetration of their hydrophobic and cationic side chains into distinct domains. Although the molecular mechanisms of these peptides are still a matter of debate, the most convincing mechanism is the interaction of AMPs with negatively charged bacterial cell surfaces through electrostatic interaction, followed by insertion into cell membranes through a hydrophobic group, leading to the disruption of membrane integrity and ultimately causing cell death. ${ }^{12}$ Alternatively, interaction with cellular targets such as enzymes and DNA/RNA after penetration of some peptides through the cell membrane inhibiting macromolecular synthesis causes cell death. Thus, the peptides may have complex mechanisms to exhibit their antimicrobial efficacy. ${ }^{13,14}$ Greater abundance of negatively charged lipids in bacterial cell membranes than in mammalian cells and zwitterionic phospholipids provide a net neutral charge on the surface of mammalian cells and introduce selectivity of cationic peptides to bind preferentially to bacteria by electrostatic attraction. ${ }^{2,15}$

Though these peptides are promising alternatives of conventional antibiotic candidates, large-scale commercial

Received: October 31, 2017

Accepted: January 4, 2018

Published: January 22, 2018 
Scheme 1. Synthesis of Leucine-Based Linear Homopolymer (P(Boc-Leu-HEMA)) (LP), Hyperbranched Copolymers (P(BocLeu-HEMA-co-VBHT)) (HBP), and Corresponding Star Polymers by RAFT Polymerization, Followed by Deprotection of the Boc Groups

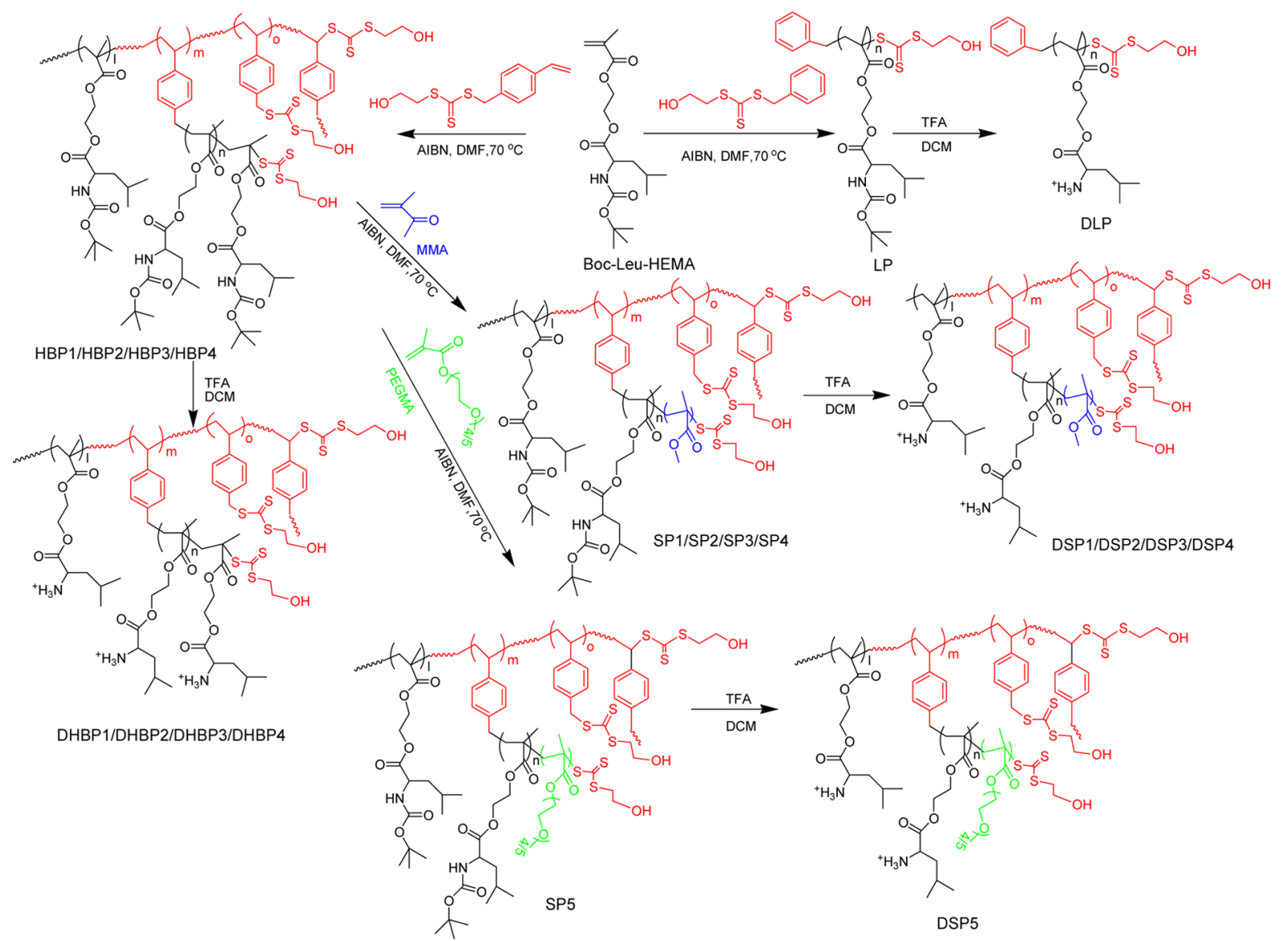

production of AMPs is largely problematic because of their complicated multistep synthesis and high manufacturing costs and also because they undergo easy proteolytic degradation. $^{13,16}$ To address these issues, biocompatible cationic polymeric materials imitating the properties of AMPs have been explored as promising replacements of conventional drugs. ${ }^{17,18}$ Amphiphilic polymethacrylates, ${ }^{19}$ polynorbornenes, ${ }^{20}$ and polyamides ${ }^{21}$ have been explored as synthetic antimicrobial agents. There have been several recent reports on synthetic antimicrobial agents utilizing new and updated approaches. Abd-El-Aziz et al. introduced antimicrobial resistance challenged with metal-based antimicrobial macromolecules. ${ }^{22}$ Nguyen et al. established the high antimicrobial efficacy of carbon monoxide by releasing a polymer against Pseudomonas aeruginosa that is highly efficient at preventing biofilm formation. ${ }^{23}$ AMP mimicking primary amine- and guanidine-containing methacrylamide copolymers prepared by reversible addition-fragmentation chain transfer (RAFT) polymerization was also investigated. ${ }^{24}$ Another report exploring the antimicrobial graft copolymer gels based on 2(methacryloyloxy)ethylphosphorylcholine and 2-hydroxypropyl methacrylate in wound dressing application has already been investigated. ${ }^{25}$ Potent and selective antimicrobial activity of polycarbonates toward Gram-positive bacteria was investigated by Nimmagadda et l. $^{3}$

Many investigations have explicated the role of structural parameters of these synthetic AMP imitating polymers in controlling antimicrobial properties. For example, the effects of amphiphilicity, ${ }^{26,27}$ molecular weight (MW), ${ }^{28}$ type of cationic charges, ${ }^{1}$ and PEGylation ${ }^{29,30}$ have been explored to control antimicrobial activity. In this regard, cationic polymer architecture is also expected to play a critical function to demonstrate antimicrobial efficacy because of the diverse orientation of cationic charges and the hydrophobic group with differential structural variation of those polymers, leading to variable bacterial cell wall penetration ability. To understand the role of the cationic polymer architecture on antibacterial efficacy and bacterial cell morphology, herein we investigated leucine-based cationic polymeric architecture-induced antibacterial activity against Gram-negative bacterium, Escherichia coli (E. coli) and bacterial cell morphology variation upon treatment at supra-minimum inhibitory concentration (supra-MIC). We have chosen a side-chain leucine-containing polymer because our previous report demonstrated the highest bacterial cell morphology switching in semisolid media [Luria Bertani (LB) agar plate] compared to other amino acid-based polymers. ${ }^{31}$ Herein, side-chain leucine-based cationic polymers having linear, hyperbranched, and star architectures were synthesized via RAFT polymerization. The highest antibacterial efficacy of star polymers was observed via bacterial growth experiment in different media and MIC determination. Polymeric architecture-tempted E. coli cell morphology at regrowth stage was explored by field emission scanning electron microscopy (FESEM), Gram staining, and confocal fluorescence microscopy after 4',6-diamidino-2-phenylindole (DAPI) staining, whereas cell coagulation, morphological switching from rod 
Table 1. Results from the Synthesis of Side-Chain Leucine-Based Homopolymer and Hyperbranched and Star Polymers via RAFT Polymerization at $70^{\circ} \mathrm{C}$ in $\mathrm{N}, \mathrm{N}$-Dimethylformamide (DMF) under Various Reaction Conditions

\begin{tabular}{|c|c|c|c|c|c|c|c|c|c|}
\hline polymer & {$[\mathrm{M}] /[\mathrm{CTA}] /[\mathrm{AIBN}]$} & time $(\mathrm{h})$ & conv. $^{f}(\%)$ & $M_{\mathrm{n}, \text { theo }} \mathrm{g}(\mathrm{g} / \mathrm{mol})$ & $M_{\mathrm{n}, \mathrm{GPC}}{ }^{h}(\mathrm{~g} / \mathrm{mol})$ & $B^{h}$ & $\mathrm{RB}(\mathrm{th})^{i}$ & $\mathrm{DB}^{j}$ & $\mathrm{RB}(\mathrm{NMR})^{k}$ \\
\hline $\mathrm{LP}^{a}$ & $20 / 1 / 0.1$ & 12 & 84 & 6000 & 48000 & 2.20 & & & \\
\hline $\mathrm{HBP} 1^{b}$ & $5 / 1 / 0.1$ & 12 & 99 & 2000 & 5700 & 1.77 & 5.950 & 0.2474 & 4.040 \\
\hline $\mathrm{HBP}^{b}$ & $10 / 1 / 0.1$ & 12 & 91 & 3400 & 20000 & 1.84 & 10.10 & 0.0755 & 13.20 \\
\hline $\mathrm{HBP}^{b}$ & $20 / 1 / 0.1$ & 12 & 85 & 6100 & 35000 & 2.14 & 18.00 & 0.0422 & 23.80 \\
\hline $\mathrm{HBP}_{4}^{b}$ & $25 / 1 / 0.1$ & 11 & 81 & 7200 & 36500 & 2.15 & 21.25 & 0.0451 & 22.17 \\
\hline $\mathrm{SP} 1^{c}$ & $15 / 1 / 0.1$ & 8 & 82 & 8200 & 4300 & 1.68 & & & \\
\hline $\mathrm{SP} 2^{c}$ & $50 / 1 / 0.1$ & 8 & 83 & 11100 & 5300 & 1.83 & & & \\
\hline $\mathrm{SP}^{c}{ }^{c}$ & $85 / 1 / 0.1$ & 8 & 81 & 13800 & 7000 & 2.80 & & & \\
\hline $\mathrm{SP} 4^{d}$ & $15 / 1 / 0.1$ & 7 & 83 & 7200 & 41700 & 1.93 & & & \\
\hline SP5 $^{e}$ & $15 / 1 / 0.1$ & 7 & 84 & 9800 & 39800 & 2.14 & & & \\
\hline
\end{tabular}

${ }^{a}[$ Monomer $(\mathrm{M})] /[\mathrm{CTA}] /[\mathrm{AIBN}]=[$ Boc-Leu-HEMA $] /[\mathrm{BBHT}] /[\mathrm{AIBN}] .^{b}[\mathrm{M}] /[\mathrm{CTA}] /[\mathrm{AIBN}]=[\mathrm{Boc}-\mathrm{Leu}-\mathrm{HEMA}] /[\mathrm{VBHT}] /[\mathrm{AIBN}] \cdot{ }^{c}[\mathrm{M}] /$ $[\mathrm{CTA}] /[\mathrm{AIBN}]=[\mathrm{MMA}] /[\mathrm{HBP} 1] /[\mathrm{AIBN}] .{ }^{d}[\mathrm{M}] /[\mathrm{CTA}] /[\mathrm{AIBN}]=[\mathrm{MMA}] /[\mathrm{HBP} 4] /[\mathrm{AIBN}] .{ }^{e}[\mathrm{M}] /[\mathrm{CTA}] /[\mathrm{AIBN}]=[\mathrm{PEGMA}] /[\mathrm{HBP} 4] /$ $[$ AIBN $] .{ }^{f}$ Calculated gravimetrically. ${ }^{g} M_{\mathrm{n} \text {,theo }}=(([$ Boc-Leu-HEMA $] /[\mathrm{CTA}] \times$ MW of Boc-Leu-HEMA $\times$ conv. $)+($ MW of CTA $)) .{ }^{h}$ Measured by GPC in tetrahydrofuran (THF). ${ }^{i}$ Theoretical repeat unit per branch $(\mathrm{RB})$, calculated from the equation $\mathrm{RB}(\mathrm{th})=([\mathrm{Boc}-\mathrm{Leu}-\mathrm{HEMA}] \times$ conv. of Boc-Leu-HEMA + 1). ${ }^{j}$ Determined by ${ }^{1} \mathrm{H}$ NMR spectroscopy, degree of branching $(\mathrm{DB})=2\left(I_{7.34-6.60} / 4-I_{4.56} / 2\right) /\left(I_{7.34-6.60} / 4+I_{1.44} / 9-1\right)$, where $I$ stands for the integration area of various chemical shift of protons. ${ }^{k} \mathrm{RB}=1 / \mathrm{DB}$.

to sphere, and lengthening of treated cells with a smooth bacterial cell wall were visualized. On the basis of these observations, the molecular mechanism of bacterial cell wall perturbation through morphological switching and cell coagulation is proposed.

\section{RESULTS AND DISCUSSION}

Polymer Design and Synthesis. We previously reported maximum bactericidal efficacy and drastic morphological switching in semisolid media from a side-chain leucine-based cationic polymer having a linear architecture compared to other amino acid (alanine and phenylalanine)-based homopolymers. ${ }^{31}$ On the basis of this observation, we have prepared a series of leucine-based cationic polymers with a structural design of linear, hyperbranched, and star architectures via the RAFT polymerization technique (Scheme 1 ) to investigate the effect of polymeric architectures on their antimicrobial activity and bacterial cell morphology. Results from the synthesis of side-chain leucine-based homopolymer, hyperbranched, and star polymers are summarized in Table 1 and discussed in the Supporting Information. Number-average MWs $\left(M_{\mathrm{n}, \mathrm{GPC}}\right)$ and polydispersity index $(D)$ values were determined from the gel permeation chromatography (GPC) analysis (Table 1 and Figure S2). The linear homopolymer was designated as LP and hyperbranched polymers were named as HBP1, HBP2, HBP3, and HBP4 for [Boc-L-leucine methacryloyloxyethyl ester (BocLeu-HEMA)]/[S-(4-vinyl)benzyl $S^{\prime}$-hydroxyethylthiocarbonate $(\mathrm{VBHT})]=5,10,20$, and 25, respectively. For both linear and hyperbranched architectures, corresponding $M_{\mathrm{n}, \mathrm{GPC}}$ values are much higher compared to the theoretical MWs $\left(M_{\mathrm{n}, \text { theo }}\right)$, which were calculated based on monomer conversion (conv.) during the RAFT polymerization. ${ }^{35}$ Three star polymers generated from the HBP1 core with the ratios 15/1/0.1, 50/1/0.1, and $85 / 1 / 0.1$ of [methyl methacrylate (MMA)]/[HBP1]/[2,2'azobisisobutyronitrile (AIBN)] are designated as SP1, SP2, and SP3, respectively. Again, $\mathrm{P}(\mathrm{HBP} 4-$ star-MMA) and $\mathrm{P}(\mathrm{HBP} 4-$ star-polyethylene glycol methyl ether methacrylate (PEGMA)) prepared at ratios $15 / 1 / 0.1$ of $[\mathrm{MMA}] /[\mathrm{HBP} 4] /[\mathrm{AIBN}]$ and $15 / 1 / 0.1$ of $[\mathrm{PEGMA}] /[\mathrm{HBP} 4] /[\mathrm{AIBN}]$ were named as SP4 and SP5, respectively. The compressed character of the star polymers can explain the much lower values of $M_{\mathrm{n}, \mathrm{GPC}}$ for the star polymers than the corresponding $M_{\mathrm{n} \text {,theo }}$ values calculated from the monomer conversion (Table 1). ${ }^{36}$ Boc-deprotected polymers (vide infra) were represented as DLP, DHBP1, DHBP2, DHBP3, DHBP4, DSP1, DSP2, DSP3, DSP4, and DSP5, where $\mathrm{D}$ stands for Boc deprotection.

Incorporation of Cationic Charges to Leucine-Based Polymer Architectures. Cationic charge is an essential requirement to disrupt negatively charged cell membrane of bacteria through electrostatic interaction. ${ }^{37}$ Hence, cationic charge was introduced to all the synthesized polymers by removing Boc groups from pendent leucine moieties in the presence of trifluoroacetic acid (TFA) at room temperature to generate polymers with primary ammonium $\left(-\mathrm{NH}_{3}^{+}\right)$salts (Scheme 1). Successful Boc deprotection was demonstrated by ${ }^{1} \mathrm{H}$ NMR spectrum, exhibiting the disappearance of Boc proton signals at around $1.44 \mathrm{ppm}$ (Figures $\mathrm{S} 3-\mathrm{S} 6$ ). The $-\mathrm{NH}_{2}$ signal was lost in the ${ }^{1} \mathrm{H}$ NMR spectrum because these protons are exchangeable with the surrounding deuterated solvent $\left(\mathrm{D}_{2} \mathrm{O}\right)$. Cationic nature of these types of polymers is already established by our group through the measurement of zeta potential. ${ }^{38,39}$

After deprotection, DLP, DHBP3, DHBP4, DSP4, and DSP5 exhibited prompt solubility in aqueous medium, making these polymers physiologically more important. ${ }^{40}$ On the contrary, delayed water solubility for DHBP1, DHBP2, DSP1, DSP2, and DSP3 was observed, which became soluble after overnight stirring. This can be explained by the greater DB of DHBP1 and DHBP2 compared to that of other hyperbranched polymers. The number of hydrophobic VBHT moieties increased with increasing $\mathrm{DB}$, hence overall hydrophobicity of DHBP1 and DHBP2 was enhanced, lowering the rate of water solubility. ${ }^{35}$ Three star polymers prepared from DHBP1 consist of both hydrophobic components: the DHBP1 core and the MMA arm, introducing overall hydrophobicity and thus lowering aqueous solubility. The ultimate water solubility of these polymers could be explained by the enhancement of overall charge density because of $-\mathrm{NH}_{3}{ }^{+}$units of the branched polymers (DHBP1 and DHBP2) with increasing DB. ${ }^{40}$

Antibacterial Activity against $E$. coli. To examine the bactericidal efficacy of leucine-based architecture variable cationic polymers, a preliminary zone of inhibition experiment was performed. Sterile agar plates were prepared, followed by inoculation with $E$. coli, and sterile filter paper disks loaded with 5,10 , and $20 \mu \mathrm{L}$ of each polymer from $10 \mathrm{mg} / \mathrm{mL}$ stock 


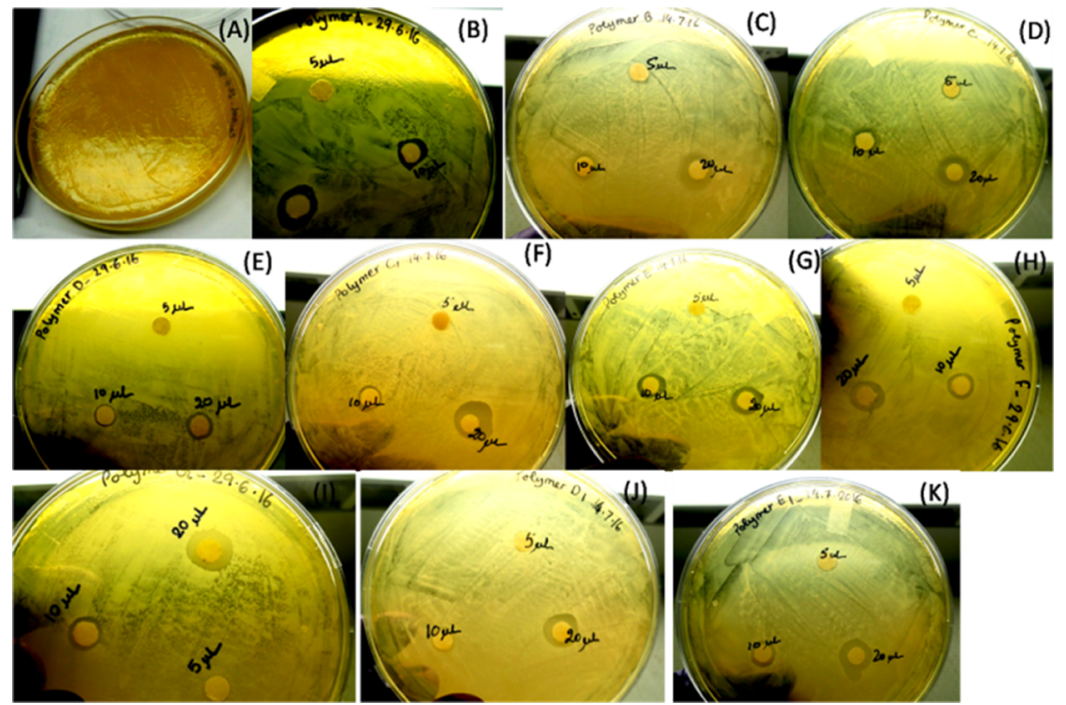

Figure 1. Zone of inhibition against E. coli: (A) control (without polymer); treatment with (B) DLP, (C) DHBP1, (D) DHBP2, (E) DHBP3, (F) DHBP4, (G) DSP1, (H) DSP2, (I) DSP3, (J) DSP4, and (K) DSP5 at 5, 10, and $20 \mu \mathrm{L}$.

Table 2. Quantitative Values of Zone of Inhibition against E. coli, MIC Calculation, and OD $_{600}$ Value Measurements after 18 h Incubation of Polymer-Treated Cells

\begin{tabular}{|c|c|c|c|c|c|c|c|c|c|c|}
\hline \multirow[b]{2}{*}{ polymer } & \multirow[b]{2}{*}{ volume $(\mu \mathrm{L})$} & \multicolumn{4}{|c|}{ radius of zone of inhibition $(\mathrm{cm})\left(R_{1}\right)$} & \multirow[b]{2}{*}{ zone of inhibition $\left(\mathrm{cm}^{2}\right)^{b}$} & \multirow[b]{2}{*}{$\operatorname{MIC}(\mu \mathrm{g} / \mathrm{mL})$} & \multirow[b]{2}{*}{$\operatorname{MIC}(\mu \mathrm{M})$} & \multirow[b]{2}{*}{ concentration $(\mu \mathrm{g} / \mathrm{mL})$} & \multirow[b]{2}{*}{$\mathrm{OD}_{600}$} \\
\hline & & set 1 & set 2 & $\mathrm{SD}^{a}$ & $\overline{R_{1} \text { (average) }}$ & & & & & \\
\hline \multirow[t]{3}{*}{ DLP } & 5 & 0.00 & 0.00 & 0 & 0.00 & 0.00 & $\sim 80$ & $\sim 1.6$ & 200 & 0.358 \\
\hline & 10 & 0.44 & 0.46 & 0.014 & 0.45 & 0.51 & & & 400 & 0.199 \\
\hline & 20 & 0.55 & 0.55 & 0 & 0.55 & 0.82 & & & 600 & 0.205 \\
\hline \multirow[t]{3}{*}{ DHBP1 } & 5 & 0.00 & 0.00 & 0 & 0.00 & 0.00 & $\mathrm{NC}^{c}$ & $\mathrm{NC}^{c}$ & $\mathrm{NC}$ & $\mathrm{NC}$ \\
\hline & 10 & 0.41 & 0.39 & 0.014 & 0.40 & 0.38 & & & $\mathrm{NC}$ & $\mathrm{NC}$ \\
\hline & 20 & 0.58 & 0.62 & 0.028 & 0.60 & 1.00 & & & $\mathrm{NC}$ & $\mathrm{NC}$ \\
\hline \multirow[t]{3}{*}{ DHBP2 } & 5 & 0.00 & 0.00 & 0 & 0.00 & 0.00 & $\mathrm{NC}$ & $\mathrm{NC}$ & $\mathrm{NC}$ & $\mathrm{NC}$ \\
\hline & 10 & 0.43 & 0.37 & 0.042 & 0.40 & 0.38 & & & $\mathrm{NC}$ & $\mathrm{NC}$ \\
\hline & 20 & 0.62 & 0.58 & 0.028 & 0.60 & 1.00 & & & $\mathrm{NC}$ & $\mathrm{NC}$ \\
\hline \multirow[t]{3}{*}{ DHBP3 } & 5 & 0.00 & 0.00 & 0 & 0.00 & 0.00 & 50 & 1.4 & 200 & 0.175 \\
\hline & 10 & 0.00 & 0.00 & 0 & 0.00 & 0.00 & & & 400 & 0.271 \\
\hline & 20 & 0.48 & 0.52 & 0.028 & 0.50 & 0.66 & & & 600 & 0.207 \\
\hline \multirow[t]{3}{*}{ DHBP4 } & 5 & 0.00 & 0.00 & 0 & 0.00 & 0.00 & $\mathrm{NC}$ & $\mathrm{NC}$ & 200 & 0.315 \\
\hline & 10 & 0.43 & 0.37 & 0.042 & 0.40 & 0.38 & & & 400 & 0.344 \\
\hline & 20 & 0.68 & 0.72 & 0.028 & 0.70 & 1.41 & & & 600 & 0.351 \\
\hline \multirow[t]{3}{*}{ DSP1 } & 5 & 0.00 & 0.00 & 0 & 0.00 & 0.00 & $\mathrm{NC}$ & $\mathrm{NC}$ & $\mathrm{NC}$ & $\mathrm{NC}$ \\
\hline & 10 & 0.43 & 0.47 & 0.028 & 0.45 & 0.51 & & & $\mathrm{NC}$ & $\mathrm{NC}$ \\
\hline & 20 & 0.50 & 0.50 & 0 & 0.50 & 0.66 & & & $\mathrm{NC}$ & $\mathrm{NC}$ \\
\hline \multirow[t]{3}{*}{ DSP2 } & 5 & 0.00 & 0.00 & 0 & 0.00 & 0.00 & $\mathrm{NC}$ & $\mathrm{NC}$ & $\mathrm{NC}$ & $\mathrm{NC}$ \\
\hline & 10 & 0.48 & 0.42 & 0.042 & 0.45 & 0.51 & & & $\mathrm{NC}$ & $\mathrm{NC}$ \\
\hline & 20 & 0.60 & 0.60 & 0 & 0.60 & 1.00 & & & $\mathrm{NC}$ & $\mathrm{NC}$ \\
\hline \multirow[t]{3}{*}{ DSP3 } & 5 & 0.00 & 0.00 & 0 & 0.00 & 0.00 & $\mathrm{NC}$ & $\mathrm{NC}$ & NC & $\mathrm{NC}$ \\
\hline & 10 & 0.39 & 0.41 & 0.014 & 0.40 & 0.38 & & & $\mathrm{NC}$ & $\mathrm{NC}$ \\
\hline & 20 & 0.55 & 0.55 & 0 & 0.55 & 0.82 & & & $\mathrm{NC}$ & $\mathrm{NC}$ \\
\hline \multirow[t]{3}{*}{ DSP4 } & 5 & 0.00 & 0.00 & 0 & 0.00 & 0.00 & $\mathrm{NC}$ & $\mathrm{NC}$ & 200 & 0.379 \\
\hline & 10 & 0.29 & 0.31 & 0.014 & 0.30 & 0.16 & & & 400 & 0.379 \\
\hline & 20 & 0.52 & 0.48 & 0.028 & 0.50 & 0.66 & & & 600 & 0.337 \\
\hline \multirow[t]{3}{*}{ DSP5 } & 5 & 0.00 & 0.00 & 0 & 0.00 & 0.00 & 50 & 1.2 & 200 & 0.075 \\
\hline & 10 & 0.42 & 0.38 & 0.028 & 0.40 & 0.38 & & & 400 & 0.109 \\
\hline & 20 & 0.55 & 0.55 & 0 & 0.55 & 0.82 & & & 600 & 0.140 \\
\hline
\end{tabular}

solution were gripped onto the top of the agar layer and incubated at $37^{\circ} \mathrm{C}$. The results of the disk susceptibility tests are visualized in Figure 1. The zone of inhibition was not observed when $5 \mu \mathrm{L}$ of the polymer was deposited. However, a clear and localized inhibition zone upon treatment of a higher volume (10 or $20 \mu \mathrm{L}$ ) of polymer solutions confirmed strong bacterial growth inhibitory effect as our polymers contain sufficient cationic and hydrophobic groups essential for 

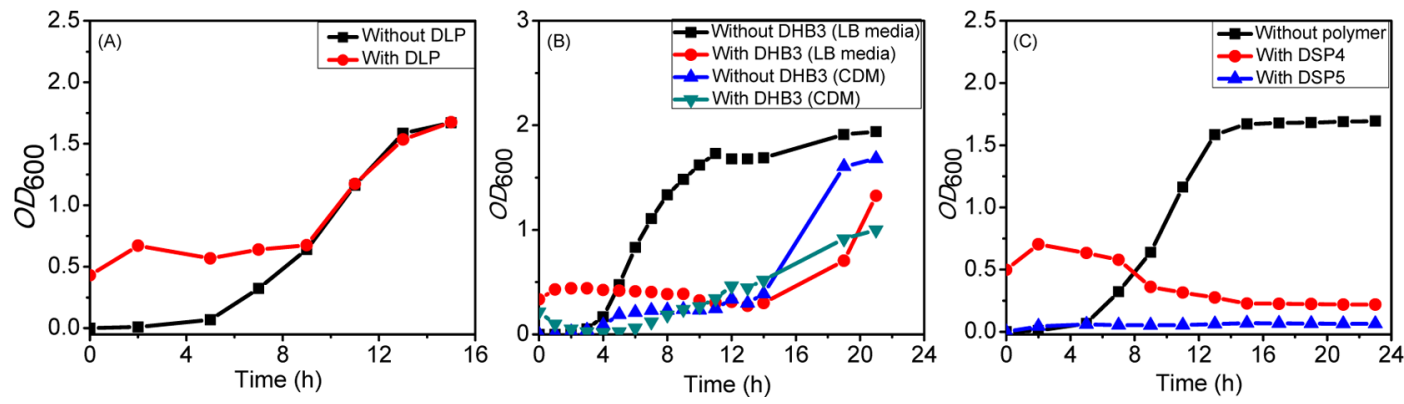

Figure 2. Growth curve of $E$. coli cells in the presence and absence of (A) DLP in LB broth media, where initial OD 600 value of DLP is 0.420 ; (B) DHBP3 in LB media and in chemically defined media (CDM), where initial OD $_{600}$ value of DHBP3 is 0.255 in LB media; (C) DSP4 and DSP5 in $\mathrm{LB}$ media, where initial $\mathrm{OD}_{600}$ values of DSP4 and DSP5 are 0.495 and 0.002 , respectively.

exhibiting bactericidal properties. ${ }^{41}$ The hyperbranched architecture bears a greater extent of cationic charges compared to the linear version, which increases with increasing DB as the charge density is proportional to $\mathrm{DB}{ }^{42}$ The isopropyl group of leucine introduced hydrophobicity for the homopolymer. For hyperbranched copolymers, additional hydrophobicity was incorporated by the phenyl groups of VBHT. Another additional hydrophobic poly(methyl methacrylate) (PMMA) block was introduced in DSP1, DSP2, DSP3, and DSP4. For DSP5, the hydrophilic PEGMA block decreased the overall hydrophobicity but enhanced the aqueous solubility. The bactericidal mechanism of cationic hydrophobic polymers is well-established. ${ }^{43}$ The cationic charge binds to the negatively charged bacterial cell wall electrostatically, followed by the insertion of hydrophobic constituents into the bacterial cell membrane, causing cell death through leakage of the cytoplasm. ${ }^{44}$ Hence, by increasing the cationic charge and hydrophobicity, the bactericidal efficacy of synthetic polymers should be enhanced. ${ }^{45}$ As our architecture variable polymers contain a different extent of cationic charge and hydrophobicity as discussed above, they should also exhibit different bactericidal properties, but the differentiation is very difficult to be observed in the zone of the inhibition method. The area of the inhibition zone (the circled portion) was calculated quantitatively and reported in Table 2 . The experiment was performed in duplicate and also with sterilized water exhibiting no inhibition zone, which established the fact that the zone of inhibition was only generated by the polymer treatment (Figure S7).

Next, the comparative cationic polymer architecture-induced bactericidal properties were visualized by the broth microdilution technique. DLP, DHBP3, and DSP5 were chosen for the comparative study from the series of polymers to determine MIC, as prompt water solubility made these polymers physiologically more important compared to others. MIC against E. coli was calculated by the turbidity-based assay, the accepted standard assay, which requires a growth medium containing nutrient proteins and fragments. ${ }^{46}$ These components in a medium may interact nonspecifically with the polymers and interfere with the physicochemical characterization of polymers in solution. MIC depends on salt concentration and buffer system of the media, ${ }^{24}$ hence these factors have to be tuned before MIC calculation. To establish the relationship between the polymer architecture and the antibacterial activity, polymers were tested in an antibacterial assay using LB broth media with phosphate buffer containing defined salt concentration and MIC values were obtained as $\sim 80,60$, and $50 \mu \mathrm{g} / \mathrm{mL}$ or $1.6,1.4$, and $1.2 \mu \mathrm{M}$, respectively, for
DLP, DHBP3, and DSP5 (Table 2). Thus, the greater antimicrobial efficacies of hyperbranched and star polymers than that of the linear architecture polymer are obtained here, which can be explained by the greater hydrophobicity and cationic charge density of these polymers than that of the linear version as discussed in the previous section. The bactericidal properties of DHBP3 and DSP5 could not be differentiated by MIC values. However, the MIC range $(50-80 \mu \mathrm{g} / \mathrm{mL})$ for our leucine-based cationic polymers with variable architecture demonstrated the greater antibacterial efficacy against E. coli in comparison to many reported primary amine-based AMP mimics. $^{24,47}$

Bacterial cells, exposed to AMPs at supra-MIC, that is, the value larger than MIC, revealed more prominent information about morphological variation. ${ }^{48}$ To obtain major information about cationic and hydrophobic leucine-based polymer architecture-triggered bacterial cell (E. coli) morphological switching, we measured $\mathrm{OD}_{600}$ at supra-MIC values $(200,400$, and $600 \mu \mathrm{g} / \mathrm{mL}$ ) for DLP, DHBP3, DHBP4, DSP4, and DSP5 (Table 2). Interestingly, some initial optical density (OD) values were obtained at these concentrations, and an instant haziness appeared after immediate addition of the abovementioned polymers except DSP5. The phenomenon can be explained by measuring the transition $\mathrm{pH}$ of each polymer. After the removal of the Boc group, side-chain leucine-based linear, hyperbranched, and star polymers are expected to show pH-responsive behavior because of their ability of protonation/ deprotonation of side-chain primary amine groups. ${ }^{49}$

Polymers were dissolved in deionized (DI) water $(2 \mathrm{mg} /$ $\mathrm{mL})$, and their $\mathrm{pH}$-induced phase transition was measured using UV-vis spectroscopy at $25{ }^{\circ} \mathrm{C}$. The initial $\mathrm{pH}$ of the solutions was adjusted to approximately 2.5 , and then the $\mathrm{pH}$ of the solution was increased in intervals of approximately $0.5 \mathrm{pH}$ units (using $0.1 \mathrm{M} \mathrm{NaOH}$ solution). After a certain time, a sudden increase in $\mathrm{pH}$ was visualized for all four polymers by adding only one drop of $\mathrm{NaOH}$. The \% transmittance (\% T) was recorded at $500 \mathrm{~nm}$ for all the polymer solutions adjusted to different $\mathrm{pH}$ values. Reduction of $50 \% \mathrm{~T}$ of the polymer solutions is reported as the phase transition $\mathrm{pH}$. For linear polymer (DLP) and hyperbranched hydrophobic copolymer (DHB3), the transition $\mathrm{pH}$ values were obtained as 6.0 and 4.6, respectively (Figure S8). Lowering of transition $\mathrm{pH}$ of $\mathrm{DHB} 3$ in comparison to that of DLP can be explained by the increase in the number of hydrophobic VBHT units, already explored by our group. ${ }^{38}$ Hence, the cloudy nature of the media $(\mathrm{pH}=7)$ after polymer addition can be explained by the lowering of transition $\mathrm{pH}(<7)$ of the polymers because of the presence of a hydrophobic functionality, leading to greater interaction with 

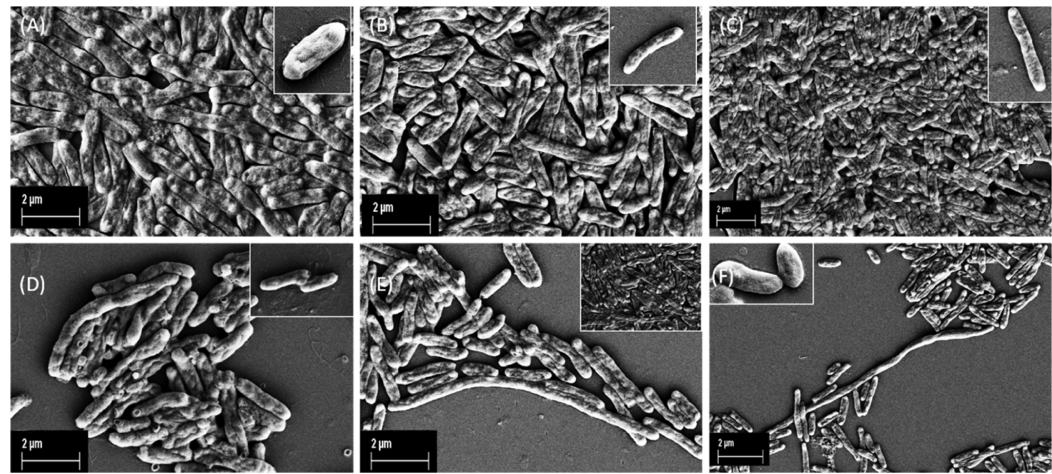

Figure 3. FESEM images of E. coli cells: (upper row) control (without polymer) at (A) 11, (B) 13, and (C) $15 \mathrm{~h}$ incubation. (Lower row) After treatment with DLP during the growth experiment in LB media at (D) 11, (E) 13, and (F) $15 \mathrm{~h}$ of incubation.

media particles. For two star polymers, DSP4 and DSP5, considerable reduction of transmittance was absent, exhibiting minimum interaction (minimum $\mathrm{OD}_{600}$ ) with media particles (Figure S8). The orientation of DSP4 in solution is such that complete reduction of transmittance was not observed, hence transition $\mathrm{pH}$ was not accurately determined, though minimum transmittance was observed at $\sim 50 \%$ because of the presence of the hydrophobic PMMA block. For DSP5, the hydrophilic PEGMA block enhanced the transition $\mathrm{pH}$ making it completely homogeneous at media $\mathrm{pH}$ and exhibited minimum interaction (minimum $\mathrm{OD}_{600}$ ) with media particles (Table 2). Nevertheless, architecture-induced comparative antimicrobial properties were investigated at the supra-MIC value $(200 \mu \mathrm{g} /$ $\mathrm{mL})$.

Antibacterial Assay of Linear Polymers against $E$. coli. Bacterial growth experiment was performed initially in LB broth media at $200 \mu \mathrm{g} / \mathrm{mL}$ of DLP. The $\mathrm{OD}_{600}$ value of the bacterial culture with and without DLP was recorded at a time interval of $2 \mathrm{~h}$ and plotted against time to obtain the bacterial growth curve (Figure $2 \mathrm{~A}$ ). Initial $\mathrm{OD}_{600}$ of DLP due to the lowering of transition $\mathrm{pH}$ and interaction with media particles was recorded as 0.420 . The bacterial growth curve generally consists of a lag phase, a log or an exponential phase, a stationary phase, and a death phase. ${ }^{50}$ When a microorganism, such as a bacterial cell, is introduced into the fresh medium, it requires some time to adjust with the new environment. This phase is termed as the lag phase, ${ }^{51}$ in which cellular metabolism is accelerated, cells are increasing in size, but the bacteria are not able to replicate, and therefore, there is no increase in cell mass. In the log phase, ${ }^{52}$ the microorganisms are in a rapidly growing and dividing state. There was an increase in metabolic activity and the number of bacterial cells at an exponential scale. At the stationary phase, ${ }^{53}$ the number of bacterial cells and hence $\mathrm{OD}_{600}$ became constant as all the nutrients in the growth medium are used up by the cells for their rapid multiplication. At the death phase, ${ }^{54}$ bacterial cell death occurs because of the depletion of nutrients. Hence, $\mathrm{OD}_{600}$ reached to a constant value. The elongation of the lag phase, that is, the required time for the bacterial culture to enter into the logarithm phase after polymer treatment, was the major investigation as the length of the lag phase depends directly on the growth condition of the organism. ${ }^{55}$ The linear polymer extended the lag phase and exhibited its growth inhibitory properties up to $9 \mathrm{~h}$ (Figure 2A). Then, the bacterial cells started growing under the antimicrobial polymer-treated environment.

The cells at higher $\mathrm{OD}_{600}$ (at 11,13 , and $15 \mathrm{~h}$ ) were collected, and the cell morphology was investigated by Gram staining (Figure S9) and FESEM experiment (Figure 3) in each of these fractions with respect to control. Single cells were very difficult to be observed by the staining method because of their smaller cell size, but lower population and coagulation of cells in the treated environment in comparison to the control set were critically visualized. Individual cell morphology was clearly established by FESEM analysis. There are several reports exhibiting polymer-treated E. coli cell images exploring the corrugated cell surface and the debris of polymer-treated cells, which established the cell wall disruption mechanism. ${ }^{44}$ Most of the FESEM images have been taken upon the exposure of antimicrobial agents at their MIC. ${ }^{16,56}$ We have performed FESEM of the E. coli cells under the regrowth stage (after their delayed lag phase) and under the exposure of DLP at the supraMIC value to obtain additional and more critical observation about bacterial cell morphology. Coagulation of treated cells was more prominently observed than Gram-staining images (Figure 3D). Elongated cells after treatment with a smooth cell surface were also critically observed with much lower population compared to the control (Figure 3E,F). A sheetlike structure was also observed upon treatment (Figure 3E, inset).

Antibacterial Assay of Hyperbranched Polymers against $E$. coli. Bacterial growth was visualized in both $\mathrm{LB}$ broth media and $\mathrm{CDM}$ by measuring $\mathrm{OD}_{600}$ values in the presence and absence of DHBP3 treated at the supra-MIC value $(200 \mu \mathrm{g} / \mathrm{mL})$ (Figure $2 \mathrm{~B})$. The delayed lag phase of the bacterial growth curve up to $15 \mathrm{~h}$ followed by the regrowth of E. coli cells (Figure 2B) was observed in the LB media, which is greater than that of DLP $(9 \mathrm{~h})$ (Figure $2 \mathrm{~A})$, and hence exhibited greater bactericidal efficiency of the hyperbranched architecture compared to that of the linear analogue. This can be explained by the increasing cationic charge and hydrophobicity of the hyperbranched structure compared to that of the linear one. ${ }^{57}$ The greater number of $-\mathrm{NH}_{3}{ }^{+}$moieties in the hyperbranched architecture electrostatically interact with the negatively charged bacterial cell wall, followed by the insertion of the hydrophobic phenyl group through the bacterial cell membrane, leading to cell wall disruption and cell death. ${ }^{46}$ Initial $\mathrm{OD}_{600}$ because of the lowering of transition $\mathrm{pH}$ and interaction with media particles was recorded as 0.255 . Interestingly, the interaction was only visualized in the $\mathrm{LB}$ broth. In CDM, the interaction between the polymer and media was absent. Compared to the LB broth, the polymer exhibited a greater bactericidal nature in $\mathrm{CDM}$ as lower $\mathrm{OD}_{600}$ established lower bacterial cell growth at higher time interval (at 19 and $23 \mathrm{~h}$ ) with respect to control. The delayed lag phase of the bacterial growth curve even in the absence of polymer 


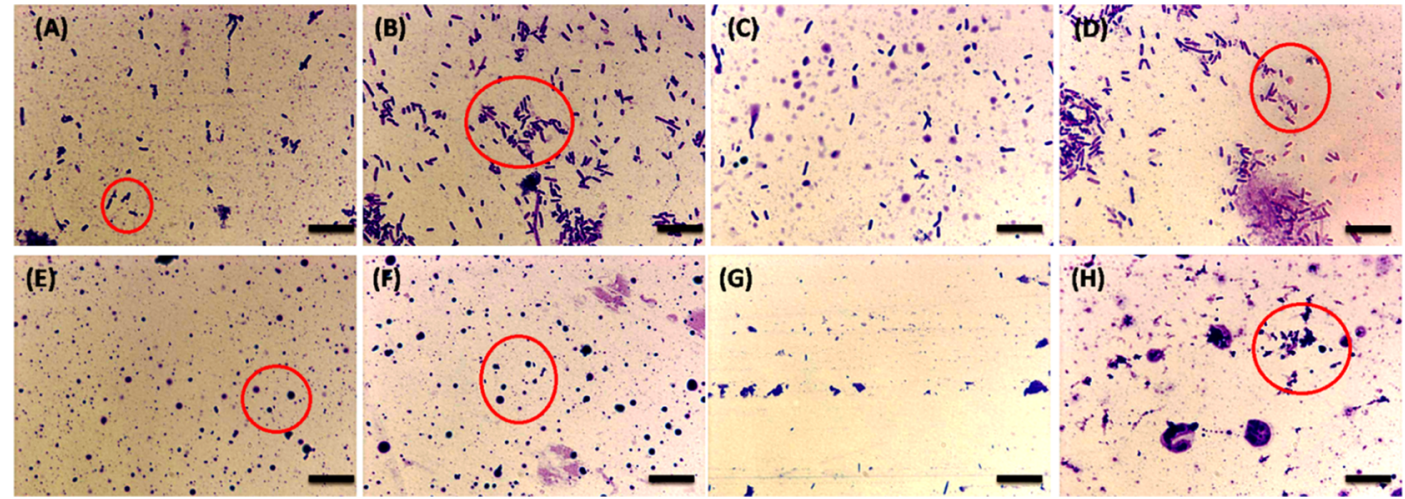

Figure 4. Optical microscopic images of E. coli cells following crystal violet staining: control at (A) 3, (B) 8, (C) 13, and (D) 19 h of incubation; DHBP3-treated E. coli cells at (E) 3, (F) 8, (G) 13, and (H) $19 \mathrm{~h}$ of incubation at $100 \times$ resolution. The black line indicates the scale bar $(20 \mu \mathrm{m})$.
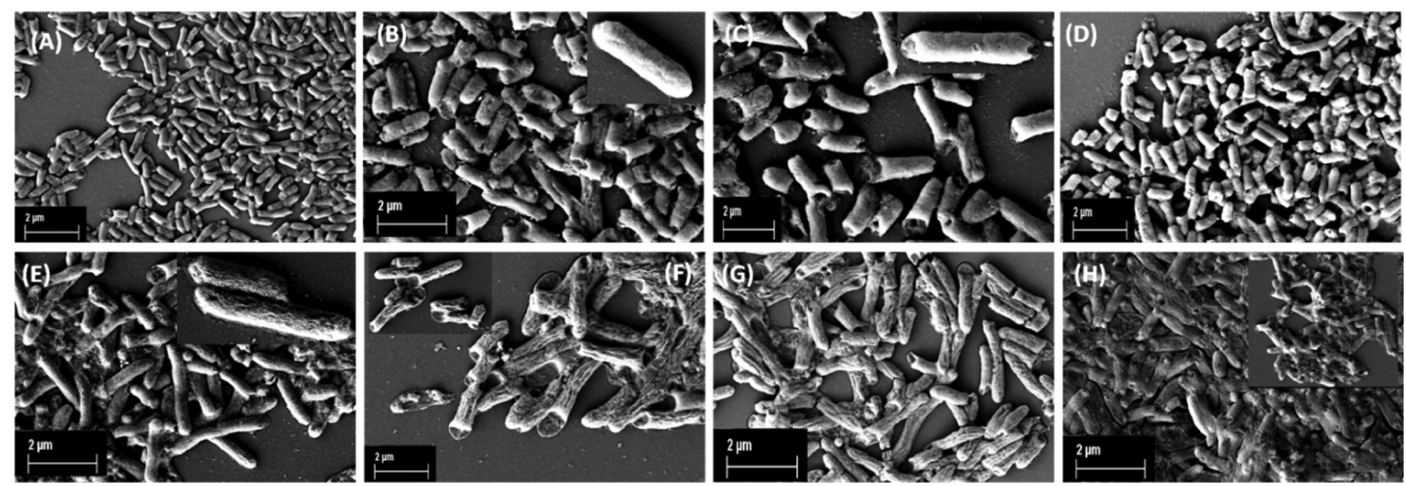

Figure 5. FESEM images of E. coli cells: (upper row) control (without polymer) at (A) 11, (B) 13, (C) 15, and (D) 19 h of incubation. (Lower row) After treatment with DHBP3 during the growth experiment in LB media at (E) 11, (F) 13, (G) 15, and (H) 19 h of incubation.

treatment in CDM compared to the LB broth media established the superiority of LB over CDM for the growth experiment as in CDM bacteria needed greater time to adjust with the environment. Nevertheless, the growth experiment in CDM in addition to generally used LB broth media established a bactericidal property of the hyperbranched polymer at different media and different interactive nature of the polymer with media particles.

To obtain morphological information, cell pellets were collected from LB broth media at different time intervals to perform Gram staining, crystal violet staining (Figures 4, S10, and S11), and FESEM experiment (Figure 4). Individual cell morphology was difficult to be observed in the Gram-staining experiment because of the smaller cell size (Figure 4A,B), but crystal violet staining of cells exhibited some spherical morphology after treatment at different time intervals $(3,8$, 13 , and $19 \mathrm{~h}$ ), whereas clear rodlike morphology of E. coli was retained in the control set during the growth experiment (Figures 4A-D and S11) (marked by red spheres). The spherical morphology was mainly observed in the earlier stage (at 3 and $8 \mathrm{~h}$ ), that is, below the log phase (up to $15 \mathrm{~h}$ ) (Figure 4E,F) (marked by red spheres). Cell stacking was critically observed after treatment at near $(13 \mathrm{~h})$ and above the lag phase that is at the regrowth stage $(19 \mathrm{~h}$ ) (Figure 4G,H) (marked by red spheres). Because of the promising bactericidal efficiency, much lesser cell numbers were observed under treated conditions (Figure 4G).

To obtain additional information about E. coli cell morphology in the treated environment, cell pellets were collected below and above the regrowth stage to perform the
FESEM experiment (Figure 5). Cell size was enhanced, and the stacking of the cells was observed with respect to control (comparing Figure 5A,E). Cell population diminished significantly because of the bactericidal nature of the polymer specifically near the junction of the lag and log phases of the growth curve (at $13 \mathrm{~h}$ ) compared with control (Figure 5B,F). Some sheetlike cell stacking was also significantly visualized in the lag phase and regrowth phase after treatment (Figure $5 \mathrm{H}$ ).

Antibacterial Assay of Star Polymers against E. coli. Bacterial cells were studied in LB media in the presence of two star polymers, DSP4 and DSP5, at $200 \mu \mathrm{g} / \mathrm{mL}$ with respect to control. Results were compared with the growth curves obtained during treatment with linear and hyperbranched polymers. Most effective growth inhibitory effect was demonstrated by the growth curve obtained during treatment with polymers having a star architecture (Figure 2C). Bacterial growth was fully diminished, and the exponential log phase was absent up to $23 \mathrm{~h}$, when bacterial growth without polymer treatment reached to the stationary phase, and hence, bacterial regrowth was inhibited. Initial $\mathrm{OD}_{600}$ of DSP4 was recorded as 0.495 , whereas DSP5 exhibited initial $\mathrm{OD}_{600}=0.002$. Earlier, we have observed that hydrophilic PEGMA caused a decrease of the antibacterial activity of the amino acid-based cationic homopolymer as it could not affect the surface wettability and solubility. ${ }^{31}$ However, here the hydrophilic PEGMA unit enhanced the surface wettability of $\mathrm{DSP}^{58}$ and maximized antimicrobial efficacy among all polymer series.

Individual cell morphology was visualized by FESEM by collecting the cell pellets after the treatment with DSP5 at $15 \mathrm{~h}$ incubation during the growth experiment. Rough cell surface, 

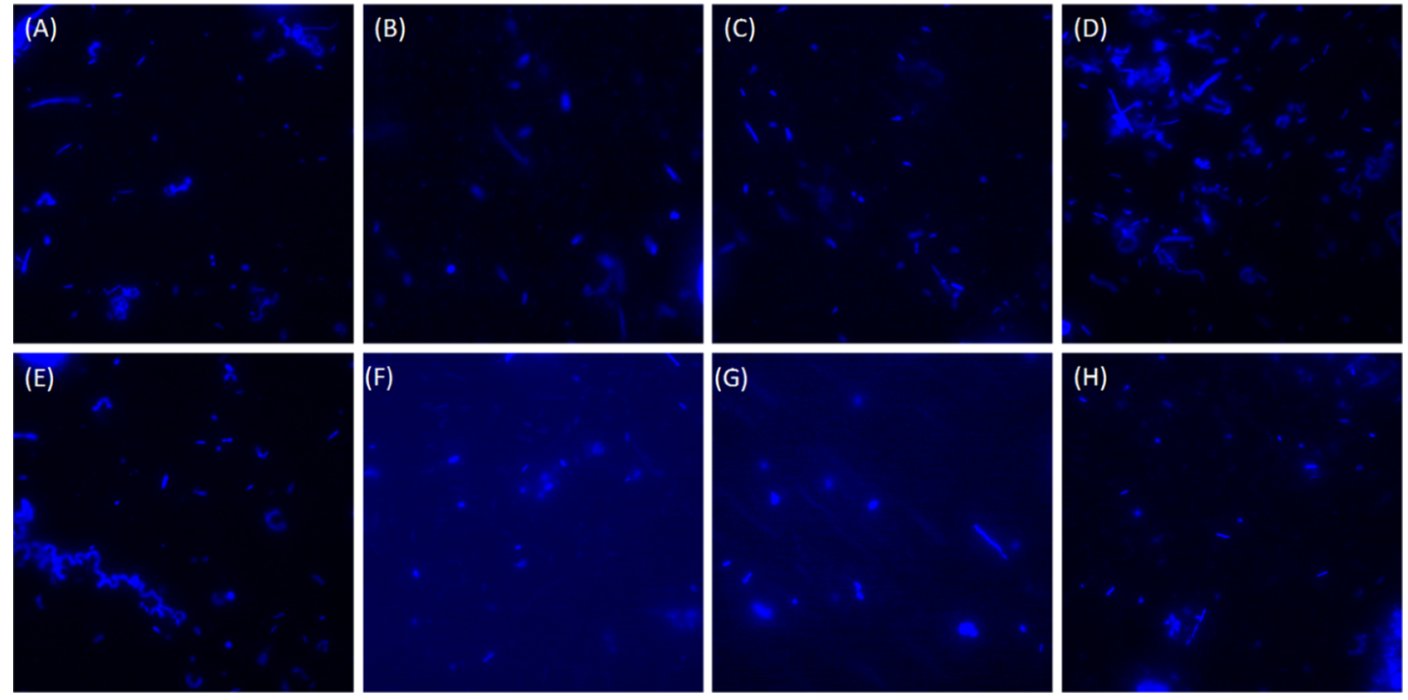

Figure 6. Confocal fluorescence microscopy images of E. coli cells (control) at (A) 13 and (B) $15 \mathrm{~h}$; after treatment with DLP during the growth experiment at (C) 11, (D) 13, and (E) $15 \mathrm{~h}$ of incubation; after treatment with DSP5 at (F) 11, (G) 13, and (H) 15 h of incubation after DAPI staining.

cell blisters, and longer cells (marked by a red circle in Figure S12B) were observed because of electrostatic and hydrophobic interaction of the polymer with E. coli cells (Figure S12). Cell pellets of earlier time intervals could not be generated by centrifugation for the SEM experiment because of lower cell population in media caused by the strongest bactericidal properties of DSP5.

The number of cells $\left(N_{t}\right)$ at any given time point $(t)$ was calculated from the corresponding growth curves (Table S1). Significant differences in $N_{t}$ values were also cross-checked using one-way analysis of variance, which is a collection of statistical models employed to analyze the differences among group means and their associated procedures (such as "variation" among and between groups), developed by statistician and evolutionary biologist Ronald Fisher. The significance of decrease in cell population was determined by the test of significance and the calculated probability $(P)$ value. The significance level for a given hypothesis test is such a value for which a $P$-value less than or equal to is considered statistically significant. Typical values for significance are 0.1, 0.05 , and 0.01 . These values correspond to the probability of observing such an extreme value by chance. On the basis of this fact, we can conclude that decrease in cell population was not statistically significant during the treatment with DLP and DHB3 in CDM, but a significant decrease in the cell number was observed upon treatment of DHB3 in LB media $(P \geq$ $0.001)$ and DSP4 $(P>0.1)$ and DSP5 $(P \geq 0.01)$ (Table S1). Hence, the greater antibacterial efficacy of the star architecture compared to that of the hyperbranched and linear ones is proved statistically.

Proposed Antibacterial Mechanism against E. coli. The mode of action of leucine-based cationic polymers having different architectures was evaluated by optical microscopy and confocal fluorescence microscopy using a well-documented live/dead bacterial assay based on the DAPI fluorescent dye probe. DAPI binds with the nucleic acid of both live/dead bacteria and stains blue. ${ }^{59}$ The staining images were exhibited in Figure 6 with a positive control comprising the lowest antimicrobial DLP-treated and the highest antimicrobial DSP5treated E. coli cells and untreated live bacterial cells as a negative control collected during the growth experiment in LB media at 11,13 , and $15 \mathrm{~h}$ of incubation. The bacterial cell wall and morphology could not remain intact during treatment. Some spherical cells appeared, indicating rod to spherical switching during treatment (Figure 6C,F,G). Cells were stacked to each other and became longer, especially under the exposure of the linear polymer (Figure 6D,E), already established by FESEM (Figure 3E,F). The highest length of the linear polymer-treated cell was explained by the faster rise of the growth curve compared to other curves obtained upon treatment of hyperbranched and star polymers; hence, longer bacterial cells were arrested in the lag phase upon treatment with DLP. ${ }^{60}$ Coagulations of the treated cells were visualized in optical microscopy images even without staining (Figure S13, circled red).

The star polymers could form self-assembly ${ }^{35}$ which can be considered as single-molecular cationic particles. ${ }^{46}$ The cationic properties of these intramolecular aggregates enhance their electrostatic binding to anionic lipopolysaccharides on the $E$. coli cell surface and lead to the substitution of the divalent cations, which are the stabilizing agents of the outer membrane. Hence, permeability of the outer membrane would increase the promotion of the uptake of the polymers by the cell surfaces like AMPs. ${ }^{61}$ The diffusion of the polymer through the peptidoglycan layer leads to electrostatic interaction with anionic lipids of inner cytoplasmic membranes, followed by the insertion of hydrophobic groups, causing membrane disruption $^{62}$ and leading to lethal leakage of cellular contents. Hence, strong perturbation of the cell wall integrity would enhance with increasing cationic and hydrophobic group. During this perturbation stage, morphological switching and cell stacking leading to a longer cell were observed. For linear and hyperbranched polymers, the mechanism is same as discussed above. Different extent of cationic and hydrophobic groups can explain the discrepancy of antimicrobial action. Thus, the role of polymer architecture on antibacterial mechanism can be established in a significant way.

Antibacterial Activity against Bacillus subtilis. DLP and DSP5 were further used on Gram-positive B. subtilis bacterium, and their activity was investigated by the zone of inhibition 


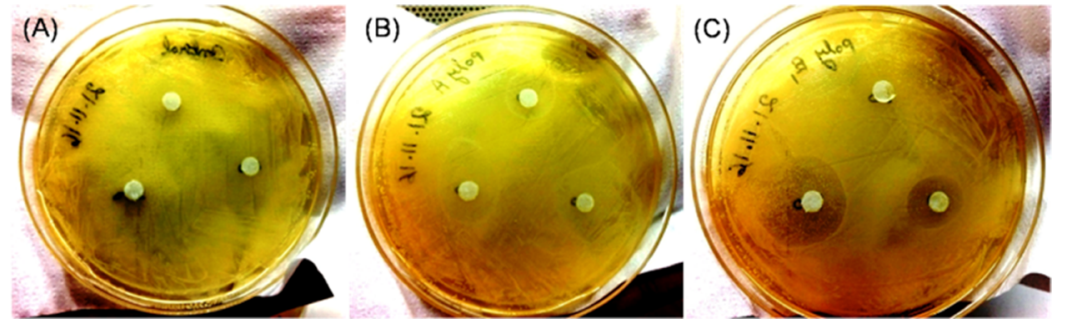

Figure 7. Zone of inhibition experiment against B. subtilis: (A) control (without polymer), treatment with (B) DLP and (C) DSP5 at (1) 50, (2) 100 , and (3) $200 \mu \mathrm{L}$

method. Sterile agar plates were prepared, followed by inoculation with $B$. subtilis, and sterile filter paper disks were loaded with 5,10 , and $20 \mu \mathrm{L}$ of each polymer from $10 \mathrm{mg} / \mathrm{mL}$ stock solution gripped onto the top of the agar layer and incubated at $37{ }^{\circ} \mathrm{C}$, but no inhibition zone was observed (Figure S14). Next, the experiment was performed upon the exposure of 50,100 , and $200 \mu \mathrm{L}$ of polymer solution from the same stock and growth was inhibited partially (Figure 7) as some cells are visible within the inhibition zone, the circled portion (Figure 7), but the number is much less compared to the other portion of the plate. These phenomena established lower antibacterial activity of our polymers on B. subtilis compared to that on E. coli. The cell wall of a Gram-negative bacterium is more anionic and hydrophilic compared to that of the Gram-positive one and hence leads to stronger electrostatic interaction between the anionic cell wall and the cationic polymer, leading to greater bactericidal efficacy to E. coli. ${ }^{63}$

\section{CONCLUSIONS}

In this report, we have presented bactericidal capacity of cationic polymers having different architectures by obtaining a localized inhibition zone. The variable architectures of sidechain leucine-based cationic polymers are the key determining factors of antimicrobial activity against Gram-negative bacterium E. coli and treated bacterial cell morphology. Hyperbranched and star polymers displayed an excellent bactericidal capability compared to the mostly used linear counterpart, visualized by MIC values and bacterial growth experiments. The differential antibacterial activity of the hyperbranched and star polymers was established by obtaining the bacterial growth curve in liquid media (LB broth or CDM). The complete disappearance of the bacterial regrowing stage upon treatment of star polymers indicated the phenomenon, when untreated cells (control) already reached to the stationary phase, whereas the bacterial regrowth stage with a delayed lag phase was critically observed for the linear and hyperbranched architectures exhibiting lower bactericidal efficacy. Bacterial cell morphology during the growth stage in liquid media at different time intervals after antibacterial and architecture variable polymer treatment was visualized by Gram staining, FESEM, and confocal fluorescence microscopy after DAPI staining, resulting in coagulation of cells, cell lengthening due to stacking, and some rod to spherical transformation. Much lower antimicrobial efficacy against Gram-positive B. subtilis was explored by these polymers via the zone of inhibition method. Hence, this investigation highlights the potential of cationic polymeric architecture to improve the antimicrobial activity, followed by the establishment of the antimicrobial mechanism against E. coli proceeding through morphological switching involving cell wall perturbation and cell surface coagulation.
Experimental Section. Materials. Boc-L-leucine (Boc-LLeu-OH, 99\%), 4-dimethylaminopyridine (99\%), dicyclohexylcarbodiimide (99\%), HEMA (97\%), 4-vinyl benzyl chloride (90\%), potassium phosphate tribasic $\left(\mathrm{K}_{3} \mathrm{PO}_{4}, 98 \%\right)$, 2mercaptoethanol, anhydrous DMF (99.9\%), and phosphatebuffered saline (PBS) tablets were purchased from SigmaAldrich. TFA (99.5\%) was received from Sisco Research Laboratories Pvt. Ltd., India. MMA (Sigma-Aldrich, 99\%) and PEGMA (MW 300 g/mol, Sigma-Aldrich, 99\%) were passed through a basic alumina column prior to polymerization. AIBN (Sigma-Aldrich, 98\%) was recrystallized twice from methanol. $\mathrm{CDCl}_{3}(99.8 \% \mathrm{D})$ and $\mathrm{D}_{2} \mathrm{O}(99 \% \mathrm{D})$ were purchased from Cambridge Isotope Laboratories, Inc., USA. Boc-Leu-HEMA was synthesized as reported elsewhere. ${ }^{32}$ Solvents such as hexanes (mixture of isomers), acetone, dichloromethane, THF, and so forth were purified by standard procedures. Benzyl chloride, carbon disulfide, agar-agar, tryplone, sodium chloride, sodium phosphate dibasic, potassium phosphate monobasic, ammonium chloride, glucose, magnesium sulfate, calcium chloride, and yeast extract were obtained from Merck, India. Petriplates were obtained from Tarsons Products Pvt. Ltd., India. Milli-Q filtered water was used to prepare solutions and autoclaved before being used. The bacterial strains used for the experimental purposes were E. coli XL10 and B. subtilis. DAPI (Amresco, USA) was used for the staining of live and fixed bacterial cells.

Instrumentation. GPC measurements were conducted in THF at $30{ }^{\circ} \mathrm{C}$ at a flow rate of $1.0 \mathrm{~mL} / \mathrm{min}$. The GPC system contains a Waters model 515 HPLC pump, one PolarGel-M guard column, two PolarGel-M analytical columns $(300 \times 7.5$ $\mathrm{mm}$ ), and one Waters model 2414 refractive index detector. Narrow MW PMMA standards (peak average MW $\left(M_{\mathrm{p}}\right)$ values ranging from 1280 to $199000 \mathrm{~g} / \mathrm{mol}$ ) were used to calibrate the GPC system. NMR spectra were acquired using a Bruker AVANCE III $500 \mathrm{MHz}$ spectrometer at $25{ }^{\circ} \mathrm{C}$. Gram-staining images of bacteria cells were captured using an optical microscope before and after polymer treatment. OD measurements of bacteria growth with and without polymer at $600 \mathrm{~nm}$ $\left(\mathrm{OD}_{600}\right)$ were performed by a Hitachi U2900 spectrometer. DAPI-stained E. coli cells were examined by an Olympus confocal laser scanning microscopy (40× resolution, Nikon camera) instrument.

Synthesis of S-Benzyl $S^{\prime}$-Hydroxyethylthiocarbonate (BBHT) Chain-Transfer Agent (CTA), VBHT CTA, and Leucine-Based Polymers Having Linear, Hyperbranched, and Star Architectures. Detailed synthesis of CTA (Figure S1 and Scheme S1) and different architecture variable polymers are discussed in the Supporting Information.

Antibacterial Activity. The study of antimicrobial activity by the zone of inhibition technique, broth microdilution method, 
and bacterial growth experiment in LB broth and CDM are presented in the Supporting Information.

Gram Staining. Gram staining was performed with cells collected at different time intervals during the growth experiment with polymers having various architectures and from control set (without polymers) at the same time gap. Standard published protocol ${ }^{33}$ for Gram staining was followed, and the slides were visualized under a light microscope.

FESEM Analysis. Bacterial cell pellets (E. coli) were collected at different time intervals during the growth experiment with polymers having various architectures and from control set (without polymers) at the same time lag. The cultures were centrifuged at $5000 \mathrm{rpm}$ for $5 \mathrm{~min}$. The precipitates were washed two times with DI water and then with $1 \%$ PBS buffer solution ( $\mathrm{pH} 7.2$ ). One microliter of $2.5 \%$ glutaraldehyde in PBS was added for $0.5 \mu \mathrm{L}$ culture in the next stage. The samples were incubated at room temperature for $30 \mathrm{~min}$ and then overnight at $4{ }^{\circ} \mathrm{C}$. The pellets were collected by centrifugation and washed three times with PBS. Dehydrations of the samples were performed in different ethanol grades $(10$, $30,50,60,70,80,90$, and $100 \%$-each volume $200 \mu \mathrm{L}$ for 10 $\mathrm{min})$. Samples were incubated in $100 \%$ ethanol for $1 \mathrm{~h}$. Finally, FESEM samples were prepared: an aliquot of sample solution was drop-casted on a cover slip, dried, and coated with gold/ palladium (20:80). The images were obtained using a Carl Zeiss-Sigma instrument.

Fluorescence Microscopy. The E. coli cell pellets collected at different time intervals during the growth experiment before and after polymer treatment were centrifuged at $6000 \mathrm{rpm}$ for $15 \mathrm{~min}$ at $10{ }^{\circ} \mathrm{C}$. Then, samples were resuspended in $1 \mathrm{~mL}$ Milli-Q water, followed by centrifugation at $6000 \mathrm{rpm}$ for 15 min. The supernatant was removed, and bacterial cell pellets were washed three or four times with PBS. Next, the cells were incubated with DAPI ( $25 \mu \mathrm{L}$ in $200 \mu \mathrm{L}$ Milli-Q water) for 30 min in the dark. DAPI can stain both live and dead bacterial cells and bind with nucleic acid selectively. ${ }^{34}$ Excess dye was removed by washing three times with Milli-Q water. Then, 20 $\mu \mathrm{L}$ of glycerol and $50 \mu \mathrm{L}$ of samples were drop-casted on the glass slide and sealed. The stained cells were visualized by a confocal laser scanning microscopy instrument with an excitation wavelength at $358 \mathrm{~nm}$, and the emission spectrum was recorded at $461 \mathrm{~nm}$ (blue).

\section{ASSOCIATED CONTENT}

\section{S Supporting Information}

The Supporting Information is available free of charge on the ACS Publications website at DOI: 10.1021/acsomega.7b01674.

Synthesis of BBHT CTA, VBHT CTA, and leucinebased polymers having linear, hyperbranched, and star architectures; GPC and NMR characterization plots; zone of inhibition experiment against $E$. coli treatment; Gram-staining results; FESEM images; optical microscopic images; and zone of inhibition experiment against B. subtilis as noted in the manuscript (PDF)

\section{AUTHOR INFORMATION}

\section{Corresponding Authors}

*E-mail: pbhadury@iiserkol.ac.in (P.B.).

*E-mail: p_de@iiserkol.ac.in (P.D.).

ORCID

Anwesha Ghosh: 0000-0003-1765-9832

Priyadarsi De: 0000-0001-5486-3395

\section{Notes}

The authors declare no competing financial interest.

\section{ACKNOWLEDGMENTS}

I.M. acknowledges the Council of Scientific and Industrial Research (CSIR), Government of India, for her junior research fellowship.

\section{REFERENCES}

(1) Palermo, E. F.; Kuroda, K. Chemical Structure of Cationic Groups in Amphiphilic Polymethacrylates Modulates the Antimicrobial and Hemolytic Activities. Biomacromolecules 2009, 10, 1416-1428.

(2) Michl, T. D.; Locock, K. E. S.; Stevens, N. E.; Hayball, J. D.; Vasilev, K.; Postma, A.; Qu, Y.; Traven, A.; Haeussler, M.; Meagher, L.; Griesser, H. J. RAFT-derived antimicrobial polymethacrylates: elucidating the impact of end-groups on activity and cytotoxicity. Polym. Chem. 2014, 5, 5813-5822.

(3) Nimmagadda, A.; Liu, X.; Teng, P.; Su, M.; Li, Y.; Qiao, Q.; Khadka, N. K.; Sun, X.; Pan, J.; Xu, H.; Li, Q.; Cai, J. Polycarbonates with Potent and Selective Antimicrobial Activity toward Gram-Positive Bacteria. Biomacromolecules 2017, 18, 87-95.

(4) She, F.; Nimmagadda, A.; Teng, P.; Su, M.; Zuo, X.; Cai, J. Helical 1:1 $\alpha$ /Sulfono- $\gamma$-AA Heterogeneous Peptides with Antibacterial Activity. Biomacromolecules 2016, 17, 1854-1859.

(5) Yapucu Güneş, Ü.; Eşer, İ. Effectiveness of a Honey Dressing for Healing Pressure Ulcers. J. Wound, Ostomy Cont. Nurs. 2007, 34, 184190.

(6) Ceylan, G.; Yılmaz, N.; Nisbet, H. Ö.; Nisbet, C.; Dede, D. Ö.; Hoşgör, F.; Kunt, G. E. Honey in wound care in complete denture wearers: a pilot study. Mater. Res. Innovat. 2010, 14, 268-270.

(7) Storm-Versloot, M. N.; Vos, C. G.; Ubbink, D. T.; Vermeulen, H. Topical silver for preventing wound infection. Cochrane Database of Systematic Reviews; John Wiley \& Sons, Ltd., 2010; pp 1-110.

(8) Bergin, S.; Wraight, P. Silver based wound dressings and topical agents for treating diabetic foot ulcers. Cochrane Database of Systematic Reviews; John Wiley \& Sons, Ltd., 2006; pp 1-24.

(9) Muñoz-Bonilla, A.; Fernández-García, M. The roadmap of antimicrobial polymeric materials in macromolecular nanotechnology. Eur. Polym. J. 2015, 65, 46-62.

(10) Zasloff, M. Antimicrobial peptides of multicellular organisms. Nature 2002, 415, 389-395.

(11) Hancock, R. E. W.; Lehrer, R. Cationic peptides: a new source of antibiotics. Trends Biotechnol. 1998, 16, 82-88.

(12) Matsuzaki, K. Why and how are peptide-lipid interactions utilized for self-defense? Magainins and tachyplesins as archetypes. Biochim. Biophys. Acta, Biomembr. 1999, 1462, 1-10.

(13) Hancock, R. E. W.; Sahl, H.-G. Antimicrobial and host-defense peptides as new anti-infective therapeutic strategies. Nat. Biotechnol. 2006, 24, 1551-1557.

(14) Brogden, K. A. Antimicrobial peptides: pore formers or metabolic inhibitors in bacteria? Nat. Rev. Microbiol. 2005, 3, 238-250.

(15) Matsuzaki, K. Control of cell selectivity of antimicrobial peptides. Biochim. Biophys. Acta, Biomembr. 2009, 1788, 1687-1692.

(16) Punia, A.; Mancuso, A.; Banerjee, P.; Yang, N.-L. Nonhemolytic and Antibacterial Acrylic Copolymers with Hexamethyleneamine and Poly(ethylene glycol) Side Chains. ACS Macro Lett. 2015, 4, 426-430.

(17) Palermo, E. F.; Kuroda, K. Structural determinants of antimicrobial activity in polymers which mimic host defense peptides. Appl. Microbiol. Biotechnol. 2010, 87, 1605-1615.

(18) Tew, G. N.; Scott, R. W.; Klein, M. L.; DeGrado, W. F. De Novo Design of Antimicrobial Polymers, Foldamers, and Small Molecules: From Discovery to Practical Applications. Acc. Chem. Res. 2010, 43, 30-39.

(19) Kuroda, K.; DeGrado, W. F. Amphiphilic Polymethacrylate Derivatives as Antimicrobial Agents. J. Am. Chem. Soc. 2005, 127, 4128-4129. 
(20) Ilker, M. F.; Nüsslein, K.; Tew, G. N.; Coughlin, E. B. Tuning the Hemolytic and Antibacterial Activities of Amphiphilic Polynorbornene Derivatives. J. Am. Chem. Soc. 2004, 126, 15870-15875.

(21) Mowery, B. P.; Lee, S. E.; Kissounko, D. A.; Epand, R. F.; Epand, R. M.; Weisblum, B.; Stahl, S. S.; Gellman, S. H. Mimicry of Antimicrobial Host-Defense Peptides by Random Copolymers. J. Am. Chem. Soc. 2007, 129, 15474-15476.

(22) Abd-El-Aziz, A. S.; Agatemor, C.; Etkin, N. Antimicrobial resistance challenged with metal-based antimicrobial macromolecules. Biomaterials 2017, 118, 27-50.

(23) Nguyen, D.; Nguyen, T.-K.; Rice, S. A.; Boyer, C. CO-Releasing Polymers Exert Antimicrobial Activity. Biomacromolecules 2015, 16, 2776-2786.

(24) Exley, S. E.; Paslay, L. C.; Sahukhal, G. S.; Abel, B. A.; Brown, T. D.; McCormick, C. L.; Heinhorst, S.; Koul, V.; Choudhary, V.; Elasri, M. O.; Morgan, S. E. Antimicrobial Peptide Mimicking Primary Amine and Guanidine Containing Methacrylamide Copolymers Prepared by Raft Polymerization. Biomacromolecules 2015, 16, 3845-3852.

(25) Harvey, A. C.; Madsen, J.; Douglas, C. W. I.; MacNeil, S.; Armes, S. P. Antimicrobial Graft Copolymer Gels. Biomacromolecules 2016, 17, 2710-2718.

(26) Lienkamp, K.; Tew, G. N. Synthetic Mimics of Antimicrobial Peptides-A Versatile Ring-Opening Metathesis Polymerization Based Platform for the Synthesis of Selective Antibacterial and CellPenetrating Polymers. Chem.-Eur. J. 2009, 15, 11784-11800.

(27) Lienkamp, K.; Madkour, A. E.; Musante, A.; Nelson, C. F.; Nüsslein, K.; Tew, G. N. Antimicrobial Polymers Prepared by ROMP with Unprecedented Selectivity: A Molecular Construction Kit Approach. J. Am. Chem. Soc. 2008, 130, 9836-9843.

(28) Mowery, B. P.; Lindner, A. H.; Weisblum, B.; Stahl, S. S.; Gellman, S. H. Structure-activity Relationships among Random Nylon-3 Copolymers That Mimic Antibacterial Host-Defense Peptides. J. Am. Chem. Soc. 2009, 131, 9735-9745.

(29) Chakrabarty, S.; King, A.; Kurt, P.; Zhang, W.; Ohman, D. E.; Wood, L. F.; Lovelace, C.; Rao, R.; Wynne, K. J. Highly Effective, Water-Soluble, Hemocompatible 1,3-Propylene Oxide-Based Antimicrobials: Poly[(3,3-quaternary/PEG)-copolyoxetanes]. Biomacromolecules 2011, 12, 757-769.

(30) Allison, B. C.; Applegate, B. M.; Youngblood, J. P. Hemocompatibility of Hydrophilic Antimicrobial Copolymers of Alkylated 4-Vinylpyridine. Biomacromolecules 2007, 8, 2995-2999.

(31) Mukherjee, I.; Ghosh, A.; Bhadury, P.; De, P. Side-Chain Amino Acid-Based Cationic Antibacterial Polymers: Investigating the Morphological Switching of a Polymer-Treated Bacterial Cell. ACS Omega 2017, 2, 1633-1644.

(32) Sun, H.; Gao, C. Facile Synthesis of Multiamino Vinyl Poly(amino acid)s for Promising Bioapplications. Biomacromolecules 2010, 11, 3609-3616.

(33) Wilhelm, M. J.; Sheffield, J. B.; Sharifian Gh., M.; Wu, Y.; Spahr, C.; Gonella, G.; Xu, B.; Dai, H.-L. Gram's Stain Does Not Cross the Bacterial Cytoplasmic Membrane. ACS Chem. Biol. 2015, 10, 17111717.

(34) Padhee, S.; Hu, Y.; Niu, Y.; Bai, G.; Wu, H.; Costanza, F.; West, L.; Harrington, L.; Shaw, L. N.; Cao, C.; Cai, J. Non-hemolytic $\alpha$ AApeptides as antimicrobial peptidomimetics. Chem. Commun. 2011, 47, 9729-9731.

(35) Ghosh Roy, S.; De, P. Facile RAFT synthesis of side-chain amino acids containing $\mathrm{pH}$-responsive hyperbranched and star architectures. Polym. Chem. 2014, 5, 6365-6378.

(36) Kafouris, D.; Gradzielski, M.; Patrickios, C. S. Synthesis and Characterization of Large-Core Star Polymers and Polymer Networks: Effects of Arm Length and Composition of the Cross-Linking Mixture. Macromol. Chem. Phys. 2009, 210, 367-376.

(37) Locock, K. E. S.; Michl, T. D.; Valentin, J. D. P.; Vasilev, K.; Hayball, J. D.; Qu, Y.; Traven, A.; Griesser, H. J.; Meagher, L.; Haeussler, M. Guanylated Polymethacrylates: A Class of Potent Antimicrobial Polymers with Low Hemolytic Activity. Biomacromolecules 2013, 14, 4021-4031.
(38) Bauri, K.; Roy, S. G.; Pant, S.; De, P. Controlled Synthesis of Amino Acid-Based pH-Responsive Chiral Polymers and Self-Assembly of Their Block Copolymers. Langmuir 2013, 29, 2764-2774.

(39) Haldar, U.; Nandi, M.; Ruidas, B.; De, P. Controlled synthesis of amino-acid based tadpole-shaped organic/inorganic hybrid polymers and their self-assembly in aqueous media. Eur. Polym. J. 2015, 67, 274-283.

(40) Pouton, C. W. Formulation of poorly water-soluble drugs for oral administration: Physicochemical and physiological issues and the lipid formulation classification system. Eur. J. Pharm. Sci. 2006, 29, $278-287$.

(41) Muñoz-Bonilla, A.; Fernández-García, M. Polymeric materials with antimicrobial activity. Prog. Polym. Sci. 2012, 37, 281-339.

(42) Plamper, F. A.; Ruppel, M.; Schmalz, A.; Borisov, O.; Ballauff, M.; Müller, A. H. E. Tuning the Thermoresponsive Properties of Weak Polyelectrolytes: Aqueous Solutions of Star-Shaped and Linear Poly(N,N-dimethylaminoethyl Methacrylate). Macromolecules 2007, 40, 8361-8366

(43) Sambhy, V.; Peterson, B. R.; Sen, A. Antibacterial and Hemolytic Activities of Pyridinium Polymers as a Function of the Spatial Relationship between the Positive Charge and the Pendant Alkyl Tail. Angew. Chem., Int. Ed. 2008, 47, 1250-1254.

(44) Guo, J.; Xu, Q.; Zheng, Z.; Zhou, S.; Mao, H.; Wang, B.; Yan, F. Intrinsically Antibacterial Poly(ionic liquid) Membranes: The Synergistic Effect of Anions. ACS Macro Lett. 2015, 4, 1094-1098.

(45) Timofeeva, L.; Kleshcheva, N. Antimicrobial polymers: mechanism of action, factors of activity, and applications. Appl. Microbiol. Biotechnol. 2011, 89, 475-492.

(46) Oda, Y.; Kanaoka, S.; Sato, T.; Aoshima, S.; Kuroda, K. Block versus Random Amphiphilic Copolymers as Antibacterial Agents. Biomacromolecules 2011, 12, 3581-3591.

(47) Punia, A.; He, E.; Lee, K.; Banerjee, P.; Yang, N.-L. Cationic amphiphilic non-hemolytic polyacrylates with superior antibacterial activity. Chem. Commun. 2014, 50, 7071-7074.

(48) Al-Badri, Z. M.; Som, A.; Lyon, S.; Nelson, C. F.; Nüsslein, K.; Tew, G. N. Investigating the Effect of Increasing Charge Density on the Hemolytic Activity of Synthetic Antimicrobial Polymers. Biomacromolecules 2008, 9, 2805-2810.

(49) Roy, S. G.; De, P. pH responsive polymers with amino acids in the side chains and their potential applications. J. Appl. Polym. Sci. 2014, 131, 41084.

(50) Buchanan, R. L.; Whiting, R. C.; Damert, W. C. When is simple good enough: a comparison of the Gompertz, Baranyi, and three-phase linear models for fitting bacterial growth curves. Food Microbiol. 1997, $14,313-326$.

(51) Baranyi, J. Stochastic modelling of bacterial lag phase. Int. J. Food Microbiol. 2002, 73, 203-206.

(52) Chang-Li, X.; Hou-Kuhan, T.; Zhau-Hua, S.; Song-Sheng, Q.; Yao-Ting, L.; Hai-Shui, L. Microcalorimetric study of bacterial growth. Thermochim. Acta 1988, 123, 33-41.

(53) Lam, H.; Oh, D.-C.; Cava, F.; Takacs, C. N.; Clardy, J.; de Pedro, M. A.; Waldor, M. K. D-Amino Acids Govern Stationary Phase Cell Wall Remodeling in Bacteria. Science 2009, 325, 1552-1555.

(54) Zwietering, M. H.; Jongenburger, I.; Rombouts, F. M.; van't Riet, K. Modeling of the Bacterial Growth Curve. Appl. Environ. Microbiol. 1990, 56, 1875-1881.

(55) Robinson, T. P.; Aboaba, O. O.; Kaloti, A.; Ocio, M. J.; Baranyi, J.; Mackey, B. M. The effect of inoculum size on the lag phase of Listeria monocytogenes. Int. J. Food Microbiol. 2001, 70, 163-173.

(56) Engler, A. C.; Tan, J. P. K.; Ong, Z. Y.; Coady, D. J.; Ng, V. W. L.; Yang, Y. Y.; Hedrick, J. L. Antimicrobial Polycarbonates: Investigating the Impact of Balancing Charge and Hydrophobicity Using a Same-Centered Polymer Approach. Biomacromolecules 2013, 14, 4331-4339.

(57) Haldar, J.; Kondaiah, P.; Bhattacharya, S. Synthesis and Antibacterial Properties of Novel Hydrolyzable Cationic Amphiphiles. Incorporation of Multiple Head Groups Leads to Impressive Antibacterial Activity. J. Med. Chem. 2005, 48, 3823-3831. 
(58) Sellenet, P. H.; Allison, B.; Applegate, B. M.; Youngblood, J. P. Synergistic Activity of Hydrophilic Modification in Antibiotic Polymers. Biomacromolecules 2007, 8, 19-23.

(59) Lebaron, P.; Parthuisot, N.; Catala, P. Comparison of Blue Nucleic Acid Dyes for Flow Cytometric Enumeration of Bacteria in Aquatic Systems. Appl. Environ. Microbiol. 1998, 64, 1725-1730.

(60) Lu, J.; Carter, D. A.; Turnbull, L.; Rosendale, D.; Hedderley, D.; Stephens, J.; Gannabathula, S.; Steinhorn, G.; Schlothauer, R. C.; Whitchurch, C. B.; Harry, E. J. The Effect of New Zealand Kanuka, Manuka and Clover Honeys on Bacterial Growth Dynamics and Cellular Morphology Varies According to the Species. PLoS One 2013, 8, No. e55898.

(61) Hancock, R. E. W. Peptide antibiotics. Lancet 1997, 349, 418422.

(62) Uppu, D. S. S. M.; Bhowmik, M.; Samaddar, S.; Haldar, J. Cyclization and Unsaturation rather than Isomerisation of Side Chains Govern the Selective Antibacterial Activity of Cationic-Amphiphilic Polymers. Chem. Commun. 2016, 52, 4644-4647.

(63) Li, P.; Zhou, C.; Rayatpisheh, S.; Ye, K.; Poon, Y. F.; Hammond, P. T.; Duan, H.; Chan-Park, M. B. Cationic Peptidopolysaccharides Show Excellent Broad-Spectrum Antimicrobial Activities and High Selectivity. Adv. Mater. 2012, 24, 4130-4137. 